\title{
Activity of dalotuzumab, a selective anti-IGF1R antibody, in combination with erlotinib in unselected patients with Non-small-cell lung cancer: a phase I/II randomized trial
}

Teresa Moran ${ }^{1 *}$, Enriqueta Felip ${ }^{2}$, Vicki Keedy ${ }^{3}$, Hossein Borghaei ${ }^{4}$, Frances A Shepherd ${ }^{5}$, Amelia Insa ${ }^{6}$, Holly Brown ${ }^{7}$, Timothy Fitzgerald ${ }^{7}$, Sriram Sathyanarayanan ${ }^{7}$, John F Reilly ${ }^{7}$ David Mauro ${ }^{7}$, Karl Hsu', Li Yan and David H Johnson ${ }^{9}$

\begin{abstract}
Background: We investigated the safety and antitumor activity of dalotuzumab, a selective anti-insulin growth factor 1 receptor monoclonal antibody (IGF1R MoAb), plus erlotinib in a sequential phase I/II trial in unselected patients with refractory advanced non-small-cell lung cancer (NSCLC).The phase I trial determined the recommended dose and safety of erlotinib plus dalotuzumab at $5 \mathrm{mg} / \mathrm{kg}$ or $10 \mathrm{mg} / \mathrm{kg}$ weekly in 20 patients. The phase II trial compared outcomes to erlotinib alone and erlotinib plus dalotuzumab at the $\mathrm{mg} / \mathrm{kg}$ established in the phase I trial.

Results: Erlotinib at $150 \mathrm{mg}$ plus dalotuzumab at $10 \mathrm{mg} / \mathrm{kg}$ was safe. The phase II trial included 37 patients in the erlotinib arm and 38 patients in the erlotinib plus dalotuzumab arm. Progression-free survival was 1.6 versus 2.5 months, overall survival was 10.2 and 6.6 months, and the objective response rate was $7.9 \%$ and $2.7 \%$, respectively, with no significant differences between the two arms. Grade 3-5 adverse events occurred in 11 (28.9\%) versus 13 (35.1\%) patients, respectively. The most frequent adverse events were asthenia (36.8\% vs. 37.8\%), dehydration (5.3\% vs. 2.7\%), diarrhea (71\% vs. 81.1\%), hyperglycemia (13.1\% vs.18.9\%), and skin-related toxicities (92.1\% vs. 86.4\%).

Conclusion: The addition of dalotuzumab to erlotinib did not improve efficacy outcome in patients with refractory advanced NSCLC.
\end{abstract}

Keywords: Non-small-cell lung cancer, Epidermal growth factor receptor, Insulin growth factor receptor, Dalotuzumab, Phase I/II trial

\section{Introduction}

Insulin-like growth factor 1 receptor (IGF1R) is overexpressed in a wide variety of human malignances, including non-small-cell lung cancer (NSCLC) [1-3]. Additionally, high co-expression of IGF1R and epidermal growth factor receptor (EGFR) has been correlated with shorter diseasefree survival in NSCLC patients [4]. Cross-talk between the EGFR and IGF1R pathways contributes to transformation, growth, and tumor responsiveness to EGFR inhibitors [5].

\footnotetext{
*Correspondence: mmoran@iconcologia.net

${ }^{1}$ Catalan Institut of Oncology-Badalona, Hospital Universitari Germans Trias i

Pujol and Universitat Autònoma de Barcelona, Barcelona, Spain

Full list of author information is available at the end of the article
}

Dalotuzumab, formerly MK-0646, is a humanized IgG1 anti-IGF1R monoclonal antibody (MoAb) that selectively binds to IGF1R without binding to insulin receptor (IR). By binding to the extracellular domain of the receptor, dalotuzumab blocks ligand binding and inhibits receptor autophosphorylation by up to $90 \%$, leading to a block in IGF1- and IGF2-mediated cell proliferation in vitro and down-regulation of cell surface receptors by $75 \%$ to $90 \%$. According to previous phase I trials, dalotuzumab reached a biologically optimal concentration when a dose of $10 \mathrm{mg} / \mathrm{kg} /$ week was administered and plasma IGF1R levels increased after dalotuzumab administration independently of the administered dose [6,7].

We hypothesized that dual inhibition of the EGFR and IGF1R pathways could prove beneficial in NSCLC 
patients. We therefore performed a phase I/II trial testing the combination of erlotinib and dalotuzumab in unselected, advanced NSCLC patients who were refractory to previous chemotherapy.

\section{Methods}

\section{Patient selection}

This study was designed as a phase I/II trial. Patients were recruited from five centers for the phase I trial and 20 centers for the phase II trial from Europe, the United States and Canada (Figure 1). Patients were eligible for inclusion if they were 18 years or older and had histologically documented advanced NSCLC refractory to previous therapy (at least one and no more than two previous chemotherapy regimens) The study was conducted in accordance with the Declaration of Helsinki and Good Clinical Practice Guidelines. The protocol was approved by local ethics committees at each participating center, and all patients gave their signed informed consent for participation in the study.

\section{Study design and treatment}

The phase I trial consisted of a safety and tolerability run-in study testing dalotuzumab at two dose levels that had previously been demonstrated as safe with an adequate pharmacodymamic profile (5 and $10 \mathrm{mg} / \mathrm{kg}$ ). Erlotinib was administered as a daily oral dose of $150 \mathrm{mg}$ and dalotuzumab as a 60-minute weekly intravenous infusion. Dalotuzumab was administered following a " $3+6$ " escalation scheme design, with an anticipated intermediate dose level of $7.5 \mathrm{mg} / \mathrm{kg}$ in the event of intolerable toxicity at the higher dose level.

In the phase II trial, patients were randomized to the control or experimental arm. Patients in the control arm received erlotinib alone, and those in the experimental arm received erlotinib plus dalotuzumab at the dose level determined by the phase I trial. Both dalotuzumab and erlotinib were provided by the sponsor of the trial, Merck Sharp \& Dohme Corp., a subsidiary of Merck \& Co, Inc., Whitehouse Station, NJ, USA.

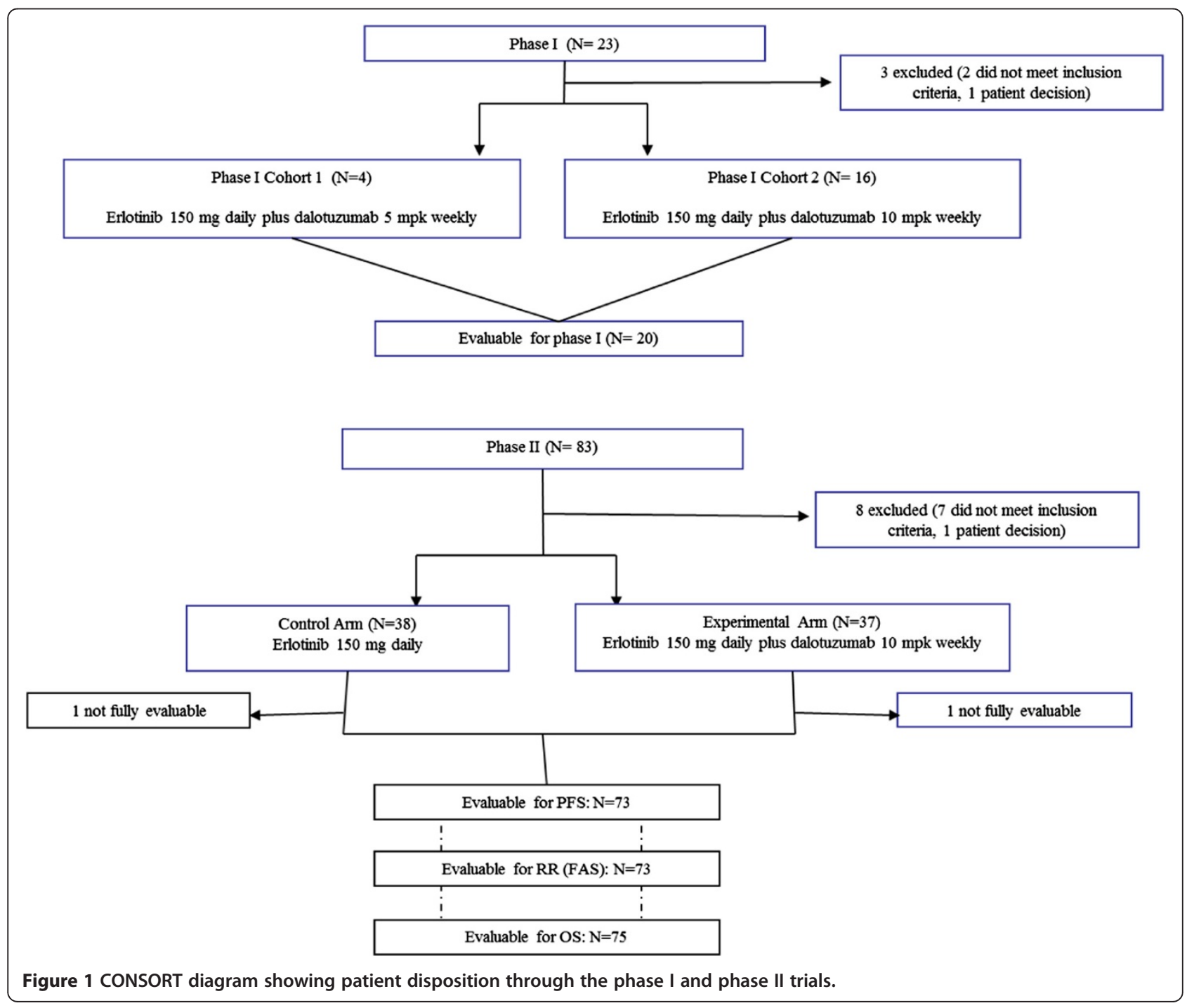




\section{Endpoints and statistical considerations}

For the phase I trial, the primary objective was to determine the safety and tolerability of erlotinib in combination with dalotuzumab in patients with advanced NSCLC. For clinical assessment of toxicity, patients were evaluated weekly and adverse events were graded according to the National Cancer Institute Common Terminology Criteria for Adverse Events version 3.0 [8]. For the purpose of determination of protocol dose escalation in phase I, dose limiting toxicity (DLT) was defined based on the events occurring within the first 4 weeks of therapy. For patient management, dose modification would occur in the event of DLT occurring during any cycle of therapy. Hematologic DLT were defined as grade 4 neutropenia lasting for $\geq 7$ days, grade 3 or 4 neutropenia with fever $>38.5^{\circ}$ and/or infection requiring antibiotics or anti-fungal therapy and grade 4 thrombocytopenia $\left(\leq 25.0 \times 10^{9} / \mathrm{L}\right)$. Non-hematologic DLT were defined as any $\geq$ grade 3 nonhematologic toxicity, with the specific exception of grade 3 skin toxicity, nausea and/or vomiting, diarrhea, dehydration or hyperglycemia that in the opinion of the investigator occurred in the setting of inadequate compliance with supportive care measures and lasted less than 48 hours.

For the phase II trial, the primary efficacy endpoint was progression-free survival (PFS); secondary endpoints were response rate, overall survival (OS) and safety and tolerability. PFS was defined as the time from randomization until either radiographic evidence of disease progression or death due to any cause, whichever occurred first. OS was defined as the time from randomization to death due to any cause. Response was graded according to the Response Evaluation Criteria in Solid Tumors (RECIST) 1.0 guidelines [9]. Radiographic evaluation was performed every six weeks during the first 48 weeks and every three months thereafter. For sample size calculation and PFS estimation, 49 PFS events in both control and experimental arms were planned and 68 patients with a projected follow-up of 5 months were needed. The present study had $80 \%$ power to detect an improvement in PFS defined as a $45.5 \%$ reduction in the hazard ratio in the combination arm. A $45.5 \%$ reduction in hazard rate corresponds to 1.84 months in improvement in median PFS compared to the erlotinib arm.

\section{Results}

\section{Patients}

From 19 Mar 2008 to 5 Jun 2009, 23 patients were enrolled in the phase I trial. Four patients were included in the first dose cohort (erlotinib $150 \mathrm{mg}$ daily orally plus dalotuzumab $5 \mathrm{mg} / \mathrm{kg} /$ week intravenously) and sixteen in the second dose cohort (erlotinib $150 \mathrm{mg}$ daily orally plus dalotuzumab $10 \mathrm{mg} / \mathrm{kg} /$ week intravenously). From 11 Aug 2010 to 24 Mar 2011, 83 patients were enrolled in the phase II trial. Eight were excluded from the analysis leaving 75 patients, 38 in the control arm and 37 in the experimental arm. Clinical characteristics for patients in both phases are summarized in Table 1. Although the phase I trial was based in a " $3+6$ " escalation scheme design, five patients were removed due to progressive disease before the first four weeks of dosing that were needed to monitor for DLTs. Three additional patients were included by decision of the study sponsor to ensure that the final sample included at least 9 fully evaluable patients.

\section{Safety}

In the phase I trial, the most common toxicities were those related to erlotinib. Thirteen patients (65\%) developed diarrhea (two grade 3 ), and $50 \%$ suffered $\leq$ grade 2 rash or acneiform dermatitis (Table 2). One patient experienced grade 3 erythema. Dalotuzumab-related toxicities include hyperglycemia in 8 patients (five grade 3). Four of these 8 patients had a previous diagnosis of diabetes mellitus and were receiving treatment for diabetes before initiating the study.

Erlotinib-related toxicities in the phase II trial included skin toxicity (reported as rash or acneiform dermatitis) in 35 (92.1\%) patients in the control arm and $32(86.4 \%)$ patients in the experimental arm, asthenia in 14 (36.8\%) and $14(37.8 \%)$ patients, dehydration in $2(5.3 \%)$ and $1(2.7 \%)$, and diarrhea in $27(71 \%)$ and $30(81.1 \%)$, respectively. Hyperglycemia was seen in 5 (13.1\%) patients in the control arm and $7(18.9 \%)$ in the experimental arm. Grade 3-5 hyperglycemia was observed in 4 (10.52\%) and 4 (10.81\%) patients, respectively. Although grade 3 to 5 adverse events are reported together, no grade 5 hyperglycemia was observed. One death, probably related to interstitial lung disease, was reported in the erlotinib arm (2.63\%) (Table 2).

\section{Efficacy}

No significant differences were observed in PFS or OS between the two treatment arms in the phase II trial. PFS was 1.6 months in the control arm and 2.5 months in the experimental arm (hazard ratio [HR]: 0.86, 95\% CI: $0.47-1.57 ; p=0.268$ ). OS was 10.2 months in the control arm and 6.6 months in the experimental arm (HR: $1.80,95 \%$ CI: 0.87-3.72; $p=0.946]$.

No significant difference in overall response rate was observed between the two arms. Three partial responses (PR) were observed in the control arm (7.9\%) and one $(2.8 \%)$ in the experimental arm, and there were no complete responses in either arm. All four patients with PR had adenocarcinomas. Twenty-one (55.3\%) patients in the control arm and 21 (56.7\%) in the experimental arm had stable disease (SD) as best response. Stable disease between 3 and 12 months was attained by seven patients in each arm (18.4\% and $18.9 \%$, respectively), and SD lasted longer than 12 months in three and two patients, respectively (Table 3). 
Table 1 Baseline patient characteristics

\begin{tabular}{|c|c|c|c|c|c|}
\hline & \multicolumn{2}{|c|}{ Phase I } & & \multicolumn{2}{|c|}{ Phase II } \\
\hline & $\begin{array}{l}\text { Dalotuzumab } 5 \mathrm{mg} / \mathrm{kg} \\
\text { plus erlotinib cohort } 1\end{array}$ & $\begin{array}{l}\text { Dalotuzumab } 10 \mathrm{mg} / \mathrm{kg} \\
\text { plus erlotinib cohort } 2\end{array}$ & & Erlotinib & $\begin{array}{l}\text { Dalotuzumab } \\
\text { plus erlotinib }\end{array}$ \\
\hline & $\mathrm{n}=4$ & $n=16$ & & $\mathrm{n}=38$ & $\mathrm{n}=37$ \\
\hline Gender & & & Gender & & \\
\hline Male & $4(100 \%)$ & $14(87.6 \%)$ & Male & $28(73.7 \%)$ & $27(73 \%)$ \\
\hline Female & $0(0 \%)$ & $2(12.5 \%)$ & Female & $10(26.3 \%)$ & $10(27 \%)$ \\
\hline Age (years) & & & Age (years) & & \\
\hline Mean & 53.8 & 61.9 & Mean & 58.5 & 61.9 \\
\hline SD & 3.9 & 7.7 & SD & 10.4 & 7.83 \\
\hline Median & 53.5 & 62.0 & Median & 59.0 & 62.0 \\
\hline Range & 50 to 58 & 50 to 72 & Range & 36 to 80 & 45 to 77 \\
\hline Race & & & Race & & \\
\hline Caucasian & $4(100 \%)$ & $16(100 \%)$ & Caucasian & $36(94.7 \%)$ & $37(100 \%)$ \\
\hline Asian & $0(0 \%)$ & $0(0 \%)$ & Asian & $2(5.3 \%)$ & $0(0 \%)$ \\
\hline ECOG performance status & & & ECOG performance status & & \\
\hline 0 & $4(100 \%)$ & $5(31.4 \%)$ & 0 & $13(34.2 \%)$ & $11(29.7 \%)$ \\
\hline 1 & $0(0 \%)$ & $11(68.8 \%)$ & 1 & $24(63.2 \%)$ & $24(64.9 \%)$ \\
\hline 2 & $0(0 \%)$ & $0(0 \%)$ & 2 & $1(2.6 \%)$ & $2(5.5 \%)$ \\
\hline Stage & & & Stage & & \\
\hline$\| \mathrm{B}$ & $1(25 \%)$ & $2(12.5 \%)$ & $\| \mathrm{IIB}$ & $9(23.7 \%)$ & $4(10.8 \%)$ \\
\hline IV & $3(75 \%)$ & $14(87.5 \%)$ & IV & $29(76.3 \%)$ & $33(89.2 \%)$ \\
\hline Smoking history & & & Smoking history & & \\
\hline Current smoker & $1(25 \%)$ & $5(31.1 \%)$ & Current smoker & 7 (18.4\%) & $12(32.4 \%)$ \\
\hline Former smoker & $3(75 \%)$ & $7(43.8 \%)$ & Former smoker & $20(52.6 \%)$ & $21(56.8 \%)$ \\
\hline Never smoker & $0(0 \%)$ & $4(25 \%)$ & Never smoker & $11(28.9 \%)$ & $4(10.8 \%)$ \\
\hline Previous therapies & & & Previous treatments & & \\
\hline Mean & 1.5 & 1.5 & First-line only & $20(52.6 \%)$ & $27(72.9 \%)$ \\
\hline Median & 1 & 1.5 & First- and second-line & $18(47.4 \%)$ & $10(27.02 \%)$ \\
\hline Range & 1 to 3 & 1 to 3 & Prior platinum-containing regimen & $38(100 \%)$ & $35(94.6 \%)$ \\
\hline $\begin{array}{l}\text { Previous diagnosis } \\
\text { of diabetes }\end{array}$ & $0(0 \%)$ & $4(25 \%)$ & $\begin{array}{l}\text { Previous diagnosis } \\
\text { of diabetes }\end{array}$ & $4(10.4 \%)$ & $2(5.4 \%)$ \\
\hline \multirow[t]{2}{*}{$\begin{array}{l}\text { Previous treatments } \\
\text { for diabetes }\end{array}$} & $0(0 \%)$ & $4(25 \%)$ & $\begin{array}{l}\text { Previous treatments } \\
\text { for diabetes }\end{array}$ & $4(10.4 \%)$ & $2(5.4 \%)$ \\
\hline & & & Glimepiridine & $1(2.6 \%)$ & $0(0 \%)$ \\
\hline Glyburide & $0(0 \%)$ & $1(6.2 \%)$ & Glyburide & $1(2.6 \%)$ & $0(0 \%)$ \\
\hline Insulin & $0(0 \%)$ & $1(6.2 \%)$ & Insulin & $0(0 \%)$ & $1(2.7 \%)$ \\
\hline Metformin & $0(0 \%)$ & $1(6.2 \%)$ & Metformin & $1(2.6 \%)$ & $1(2.7 \%)$ \\
\hline Rapaglinide & $0(0 \%)$ & $1(6.2 \%)$ & Pioglitazone & $1(2.6 \%)$ & $0(0 \%)$ \\
\hline Histology & & & Histology & & \\
\hline Adenocarcinoma & $1(25 \%)$ & $5(31.3 \%)$ & Adenocarcinoma & $15(39.5 \%)$ & $14(37.8 \%)$ \\
\hline Squamous cell carcinoma & $3(75 \%)$ & $4(25 \%)$ & Squamous cell carcinoma & $6(15.8 \%)$ & $11(29.7 \%)$ \\
\hline Large cell carcinoma & $0(0 \%)$ & $1(6.3 \%)$ & Large cell carcinoma & $0(0 \%)$ & $1(2.7 \%)$ \\
\hline Not otherwise specified & $0(0 \%)$ & $6(37.5 \%)$ & Not otherwise specified & $17(44.7 \%)$ & $11(29.7 \%)$ \\
\hline
\end{tabular}

ECOG = Eastern Cooperative Oncology Group. 
Table 2 Summary of adverse events

\begin{tabular}{|c|c|c|c|c|c|}
\hline \multirow{3}{*}{ Event } & & \multicolumn{2}{|c|}{ Phase I } & \multicolumn{2}{|r|}{ Phase II } \\
\hline & & $\begin{array}{c}\text { Dalotuzumab } \\
5 \mathrm{mg} / \mathrm{kg} \text { plus erlotinib }\end{array}$ & $\begin{array}{c}\text { Dalotuzumab } \\
10 \mathrm{mg} / \mathrm{kg} \text { plus erlotinib }\end{array}$ & Erlotinib & $\begin{array}{c}\text { Dalotuzumab } \\
10 \mathrm{mg} / \mathrm{kg} \text { plus erlotinib }\end{array}$ \\
\hline & & $\mathrm{N}=4$ & $N=16$ & $N=38$ & $N=37$ \\
\hline \multicolumn{6}{|c|}{ Diarrhea } \\
\hline & $A E$ & $1(25 \%)$ & $12(75 \%)$ & 27 (71\%) & 30 (81.1\%) \\
\hline & SAE & 0 & $2(12.6 \%)$ & 0 & 0 \\
\hline & Drug-related $A E$ & $1(25 \%)$ & $10(62.5 \%)$ & $18(47.3 \%)$ & $16(43.2 \%)$ \\
\hline & g3-5 & 0 & $2(12.5 \%)$ & $1(2.6 \%)$ & $3(8.1 \%)$ \\
\hline \multicolumn{6}{|c|}{ Nausea } \\
\hline & $\mathrm{AE}$ & 0 & $5(31.2 \%)$ & 17 (44.7\%) & 17 (45.9\%) \\
\hline & SAE & 0 & 0 & 0 & 0 \\
\hline & Drug-related AE & 0 & $3(18.7 \%)$ & $4(10.5 \%)$ & $6(16.2 \%)$ \\
\hline & g3-5 & 0 & 0 & 0 & 0 \\
\hline \multicolumn{6}{|c|}{ Stomatitis } \\
\hline & $\mathrm{AE}$ & $2(50 \%)$ & $5(31.2 \%)$ & $3(7.9 \%)$ & $4(10.8 \%)$ \\
\hline & SAE & 0 & 0 & 0 & 0 \\
\hline & Drug-related $A E$ & $1(25 \%)$ & $3(18.5 \%)$ & $2(5.3 \%)$ & $3(8.1 \%)$ \\
\hline & g3-5 & 0 & 0 & 0 & 0 \\
\hline \multicolumn{6}{|c|}{ Asthenia } \\
\hline & $\mathrm{AE}$ & $1(25 \%)$ & $10(62.5 \%)$ & $14(36.8 \%)$ & $14(37.8 \%)$ \\
\hline & SAE & 0 & 0 & $1(2.6 \%)$ & 0 \\
\hline & Drug-related $A E$ & 0 & $1(6.2 \%)$ & 7 (18.4\%) & $3(8.1 \%)$ \\
\hline & g3-5 & 0 & $1(6.2 \%)$ & $2(5.3 \%)$ & $2(5.4 \%)$ \\
\hline \multicolumn{6}{|c|}{ Hepatobiliary disorders } \\
\hline & $\mathrm{AE}$ & 0 & 0 & $4(10.5 \%)$ & $4(10.8 \%)$ \\
\hline & SAE & 0 & 0 & 0 & $2(5.4 \%)$ \\
\hline & Drug-related $A E$ & 0 & 0 & $1(2.6 \%)$ & 0 \\
\hline & g3-5 & 0 & 0 & 0 & $2(5.4 \%)$ \\
\hline \multicolumn{6}{|c|}{ Hyperglycemia } \\
\hline & $\mathrm{AE}$ & 0 & $8(50 \%)$ & $5(13.1 \%)$ & 7 (18.9\%) \\
\hline & SAE & 0 & $1(6.2 \%)$ & $1(2.6 \%)$ & $2(5.4 \%)$ \\
\hline & Drug-related AE & 0 & $2(12.5 \%)$ & $2(5.3 \%)$ & $4(10.8 \%)$ \\
\hline & g3-5 & 0 & $5(31.2 \%)$ & $4(10.5 \%)$ & $4(10.8 \%)$ \\
\hline \multicolumn{6}{|c|}{ Dehydration } \\
\hline & $A E$ & 0 & 0 & $2(5.3 \%)$ & $1(2.7 \%)$ \\
\hline & SAE & 0 & 0 & $1(2.6 \%)$ & 0 \\
\hline & Drug-related $A E$ & 0 & 0 & 0 & $1(2.7 \%)$ \\
\hline & g3-5 & 0 & 0 & $1(2.6 \%)$ & 0 \\
\hline \multicolumn{6}{|l|}{ Rash } \\
\hline & $A E$ & $1(25 \%)$ & $9(56.2 \%)$ & $24(63.1 \%)$ & $28(75.7 \%)$ \\
\hline & $S A E^{*}$ & $3(75 \%)$ & $14(87.5 \%)$ & $28(73.7 \%)$ & $25(67.6 \%)$ \\
\hline & Drug-related $\mathrm{AE}$ & $1(25 \%)$ & $8(50 \%)$ & 19 (50\%) & $20(54 \%)$ \\
\hline & g3-5 & $1(25 \%)$ & 0 & 2 (5.26\%) & $2(5.4 \%)$ \\
\hline
\end{tabular}


Table 2 Summary of adverse events (Continued)

\begin{tabular}{|c|c|c|c|c|c|}
\hline \multicolumn{6}{|l|}{ Acneiform dermatitis } \\
\hline & $A E$ & $2(50 \%)$ & $8(50 \%)$ & $11(28.9 \%)$ & $4(10.8 \%)$ \\
\hline & $S A E^{*}$ & $3(75 \%)$ & $14(87.5 \%)$ & $28(73.7 \%)$ & $25(67.6 \%)$ \\
\hline & Drug-related AE & $2(50 \%)$ & $6(37.5 \%)$ & $9(23.7 \%)$ & $3(8.1 \%)$ \\
\hline & g3-5 & 0 & 0 & $1(2.6 \%)$ & 0 \\
\hline \multicolumn{6}{|l|}{ Paronychia } \\
\hline & $\mathrm{AE}$ & $1(25 \%)$ & $1(6.2 \%)$ & $8(21.05 \%)$ & $6(16.2 \%)$ \\
\hline & SAE & 0 & 0 & 0 & 0 \\
\hline & Drug-related AE & 0 & $1(6.2 \%)$ & $5(13.1 \%)$ & $4(10.8 \%)$ \\
\hline & g3-5 & 0 & 0 & 0 & 0 \\
\hline Related deaths & & 0 & 0 & $1(2.6 \%)^{* *}$ & 0 \\
\hline Treatment discontinuations $s^{* * *}$ & & 0 & $1(6.25 \%)$ & $2(5.26 \%)$ & $1(2.7 \%)$ \\
\hline
\end{tabular}

Fourteen patients in the erlotinib arm crossed over to the experimental arm at the time of disease progression. The best response for this subgroup of patients was SD in four patients (lasting 15 months in one patient and less than three months in three patients). At the time of the first evaluation after crossover, six patients had progressed and no response assessment was done in four patients. None of the patients who crossed over harbored EGFR or KRAS mutations.

\section{Discussion}

Although the present study has confirmed the general safety and tolerability of the combination of erlotinib plus dalotuzumab in patients with advanced NSCLC, no benefit was observed in terms of efficacy. In fact, the RR for the combination of erlotinib and dalotuzumab was lower than the $8-10 \%$ obtained with standard therapies in recurrent advanced NSCLC, including not only chemotherapy but also EGFR tyrosine kinase inhibitors (TKIs) such as gefitinib and erlotinib [10,11]. Even though the sample size was small, the study was powered to detect clinically significant differences in PFS.

As expected from previous dose-escalation studies, toxicity was mild and mainly related to erlotinib [12-14].

The major concern regarding IGF1R inhibition is the risk of hyperglycemia. In a previous trial of figitumumab,

Table 3 Summary of outcomes in phase II trial

\begin{tabular}{|c|c|c|c|}
\hline \multirow[t]{2}{*}{ Outcome } & Erlotinib & $\begin{array}{c}\text { Dalotuzumab } \\
10 \mathrm{mg} / \mathrm{kg} \text { plus erlotinib }\end{array}$ & \\
\hline & $N=38$ & $\mathrm{~N}=37$ & \\
\hline Response & & & $\begin{array}{l}\text { Difference in rates: }-0.052 \\
(95 \% \text { Cl: }-0.069-0.185) ; p=0.317\end{array}$ \\
\hline Partial response & $3(7.9 \%)$ & $1(2.7 \%)$ & \\
\hline Complete response & 0 & 0 & \\
\hline Overall response & $3(7.9 \%)$ & $1(2.7 \%)$ & \\
\hline Not evaluable & $1(2.6 \%)$ & $4(10.8 \%)$ & \\
\hline Progressive disease & $14(36.8 \%)$ & $11(29.7 \%)$ & \\
\hline Stable disease & $21(55.3 \%)$ & $21(56.7 \%)$ & \\
\hline Stable disease $\leq 3$ months & $11(28.9 \%)$ & $10(27 \%)$ & \\
\hline Stable disease 4-12 months & $7(18.42 \%)$ & 7 (18.9\%) & \\
\hline Stable disease $>12$ months & $3(7.9 \%)$ & $2(5.4 \%)$ & \\
\hline Progression-free survival (months) & 1.6 & 2.5 & $\mathrm{HR}, 0.86(95 \% \mathrm{Cl}: 0.47-1.57) ; p=0.268$ \\
\hline Overall survival (months) & 10.2 & 6.6 & $\mathrm{HR}, 1.80(95 \% \mathrm{Cl}: 0.87-3.72) ; p=0.946$ \\
\hline
\end{tabular}


$15 \%$ of patients previously had been diagnosed with diabetes, and grade 3-5 hyperglycemia rates were almost $20 \%$ in both arms of the trial [15]. In our study, less than $20 \%$ of the patients in both arms had hyperglycemia (grade 3-4 in 10\% in each arm), and in all cases, it was manageable with insulin. Although grade 3 and 4 hyperglycemia was recorded, it was not considered a DLT since according to the protocol specifications the event was controlled within the first 48 hours. Moreover, hyperglycemia was well controlled in the current study in patients with a previous diagnosis of diabetes mellitus who were receiving treatment at enrollment.

The cumulative experience of using MoAbs directed against IGF1R in combination with different therapies in unselected NSCLC patients raises the question of why promising evidence in the laboratory has failed repeatedly when translated into the clinical setting. One reason could be the excessive toxicity of the combinations. For example, when anti-IGF1R MoAbs were combined with chemotherapy or erlotinib, toxicity may well have prevented the optimum synergistic effect. Conversely, and similar to our findings, the toxicity profile was quite acceptable with erlotinib plus R1507 [16]. In fact, the majority of side effects were related to erlotinib, and the addition of the anti-IGF1R MoAb did not significantly increase the risk of toxicity.

A second explanation for the failure of dual IGF1R and EGFR inhibition may lie in the influence of $K R A S$ or EGFR mutations. Patients with KRAS mutations had a higher 12-week PFS rate than those with wild-type KRAS (36\% vs. 0\%) when treated with erlotinib plus R1507 [16]. In the present study, all five patients with KRAS mutations had progressive disease. EGFR mutations did not correlate with outcome to erlotinib plus R1507 [16]. In the present study, only one of the four patients with EGFR mutations was allocated to the experimental arm. Although this patient had stable disease lasting seven months, it is impossible to draw any conclusions from this individual case.

\section{Conclusion}

In conclusion, the present study has shown that although the combination of dalotuzumab plus erlotinib is generally tolerable, it does not confer greater benefit than erlotinib alone in advanced NSCLC patients who are EGFR-TKI naive. The cumulative results of this and other studies of dual IGF1R and EGFR inhibition indicate that further investigation of such combinations is not warranted in unselected NSCLC patients.

\section{Consent}

Written inform consent form included the patient authorization for publication of data obtained from the present trial.

\section{Competing interests}

T. Moran has received travel support from Merck \& Co, Inc. V. Keedy has received grants from Merck, is a paid consultant for Ziopharm, and received grant support from Ziopharm, Yakult, U3 Pharma, Merrimack, Pfizer, Ariad, Novartis, J\&J/Janssen, Threshold, Genentech, Abraxis, Amgen and Nereus. H. Borghaei has received paid speaker bureaus from Genentech. D.H. Johnson has received an institutional grant from ECOGNanderbilt.

H. Brown, T. Fitzgerald, S. Sathyanarayanan, J.F. Reilly, D. Mauro, and L. Yan are current or former employees of Merck \& Co, Inc., Whitehouse Station, NJ, USA and may own stock/stock options in the company.

E. Felip, F. Shepherd, A. Insa, and K. Hsu have no conflicts of interest to report

\section{Authors' contributions}

TM collected and assembled data, interpreted the results, wrote the initial draft, and provided study materials or patients. EF performed or supervised analyses, provided substantive suggestions for revision or critically reviewed subsequen iterations of the manuscript, and provided statistical expertise. VK collected or assembled data and interpreted the results, provided substantive suggestions for revision or critically reviewed subsequent iterations of the manuscript, and provided study materials or patients. HB collected or assembled the data, provided substantive suggestions for revision or critically reviewed subsequent iterations of the manuscript, and provided study materials or patients. FAS and Al collected or assembled the data, provided substantive suggestions for revision or critically reviewed subsequent iterations of the manuscript, and provided study materials or patients. HB collected or assembled the data, performed or supervised analyses, and interpreted the results; and provided substantive suggestions for revision or critically reviewed subsequent iterations of the manuscript. TF conceived, designed, or planned the study; collected or assembled the data; and provided substantive suggestions for revision or critically reviewed subsequent iterations of the manuscript. JR performed or supervised analyses and interpreted results. SS conceived, designed, or planned the study; collected or assembled the data; performed or supervised analyses and interpreted results; wrote sections of the initial draft and provided substantive suggestions for revision or critically reviewed subsequent iterations of the manuscript. DM performed or supervised analyses and interpreted results, provided substantive suggestions for revision or critically reviewed subsequent iterations of the manuscript, and provided administrative, technical, or logistic support. KH conceived, designed, or planned the study; and provided substantive suggestions for revision or critically reviewed subsequent iterations of the manuscript. LY conceived, designed, or planned the study; collected or assembled data and interpreted the results; wrote sections of the initial draft; provided substantive suggestions for revision or critically reviewed subsequent iterations of the manuscript; and provided study materials or patients. $\mathrm{DH}$ interpreted the results, provided substantive suggestions for revision or critically reviewed subsequent iterations of the manuscript; and provided study materials or patients. All authors read and approved the final manuscript.

\section{Author's information}

Teresa Moran: Presented in part at the 100th Annual Meeting of the American Association for Cancer Research (April 2009) and at the IASLC 14th World Conference on Lung Cancer (July 2011).

\section{Acknowledgments}

The authors acknowledge the editorial assistance of Scott Vuocolo, PhD, Kristen Lewis, BA, and Martha Carroll Vollmer, MA, of Merck Sharp \& Dohme Corp., a subsidiary of Merck \& Co, Inc., Whitehouse Station, NJ, USA in the preparation of this manuscript.

\section{Sources of support}

Merck Sharp \& Dohme Corp., a subsidiary of Merck \& Co, Inc., Whitehouse Station, NJ, USA

\section{Author details}

${ }^{1}$ Catalan Institut of Oncology-Badalona, Hospital Universitari Germans Trias i Pujol and Universitat Autònoma de Barcelona, Barcelona, Spain. ${ }^{2}$ Vall d'Hebron University Hospital, Barcelona, Spain. ${ }^{3}$ Vanderbilt University Medical Center, Nashville, TN, USA. ${ }^{4}$ Fox Chase Cancer Center, Philadelphia, PA, USA. ${ }^{5}$ University Health Network Princess Margaret Cancer Centre, University of Toronto, Ontario, Canada. ${ }^{6}$ Hospital Clínico Universitario de Valencia, Valencia, Spain. ${ }^{7}$ Merck \& Co., Inc., Whitehouse Station, NJ, USA. ${ }^{8}$ Sanofi Aventis, Bridgewater, NJ, USA. ${ }^{9}$ UT Southwestern University, Dallas, TX, USA. 
Received: 24 October 2014 Accepted: 24 October 2014

Published: 7 November 2014

\section{References}

1. Takanami I, Imamuma T, Hashizume T, Kikuchi K, Yamamoto Y, Yamamoto T, Kodaira S: Insulin-like growth factor-II as a prognostic factor in pulmonary adenocarcinoma. J Surg Oncol 1996, 61:205-208

2. Zia F, Jacobs S, Kull F Jr, Cuttitta F, Mulshine JL, Moody TW: Monoclonal antibody alpha IR-3 inhibits non-small-cell lung cancer growth in vitro and in vivo. J Cell Biochem Supp/ 1996, 24:269-275.

3. Yu H, Spitz MR, Mistry J, Gu J, Hong WK, Wu X: Plasma levels of insulin-like growth factor-I and lung cancer risk: a case-control analysis. J Nat Cancer Inst 1999, 91:151-156.

4. Ludovini V, Bellezza G, Pistola L, Bianconi F, Di Carlo L, Sidoni A, Semeraro A, Del Sordo R, Tofanetti FR, Mameli MG, Daddi G, Cavaliere A, Tonato M, Crino L: High coexpression of both insulin-like growth factor receptor-1 (IGFR-1) and epidermal growth factor receptor (EGFR) is associated with shorter disease-free survival in resected non-small-cell lung cancer patients. Ann Oncol 2009, 20:842-849.

5. Morgillo F, Kim WY, Kim ES, Ciardiello F, Hong WK, Lee HY: Implication of the insulin-like growth factor-IR pathway in the resistance of non-small-cell lung cancer cells to treatment with gefitinib. Clin Cancer Res 2007, 13:2795-2803

6. Atzori F, Tabernero J, Cervantes A, Botero M, Hsu K, Brown H, Hanley W, Macarulla T, Rosello S, Baselga J: A phase I, pharmacokinetic (PK) and pharmacodynamic (PD) study of weekly (qW) MK-0646, an insulin-like growth factor-1 receptor (IGF1R) monoclonal antibody (MoAb) in patients (pts) with advanced solid tumors. In Presented at the 2008 ASCO Annual Meeting; May 31-June 3, 2010; Chicago, III. Abstract 3519. 2010.

7. Hidalgo M, Tirado Gomez M, Lewis N, Vulky JL, Taylor G, Hayburn JL, Hsu K, Kosh M, Picozzi VJ: A phase I study of MK-0646, a humanized monoclonal antibody against the insulin-like growth factor receptor type 1 (IGF1R) in advanced solid tumor patients in a q2 wk schedule. In Presented at the 2008 ASCO Annual Meeting; May 31-June 3, 2010; Chicago, III. Abstract 3520. 2010.

8. $\mathrm{NCl}$ Common Terminology Criteria for Adverse Events Version 3.0. http://ctep cancer.gov/protocolDevelopment/electronic applications/ctc.htm]

9. Therasse P, Arbuck SG, Eisenhauer EA, Wanders J, Kaplan RS, Rubinstein L, Verweij J, Van Glabbeke M, van Oosterom AT, Christian MC, Gwyther SG: New guidelines to evaluate the response to treatment in solid tumors. European Organization for Research and Treatment of Cancer, National Cancer Institute of the United States, National Cancer Institute of Canada. J Nat Cancer Inst 2000, 92:206-216.

10. Shepherd FA, Rodrigues Pereira J, Ciuleanu T, Tan EH, Hirsh V, Thongprasert S, Campos D, Maoleekoonpiroj S, Smylie M, Martins R, van Kooten M, Dediu M, Findlay B, Tu D, Johnston D, Bezjak A, Clark G, Santabarbara P, Seymour L, for the National Cancer Institute of Canada Clinical Trials Group: Erlotinib in previously treated non-small-cell lung cancer. N Engl J Med 2005, 353:123-132.

11. Miller VA, Hirsch V, Cadrenel J, Cadranel J, Chen YM, Park K, Kim SW, Zhou C, Su WC, Wang M, Sun Y, Heo DS, Crino L, Tan EH, Chao TY, Shahidi M, Cong XJ, Lorence RM, Yang JC: Afatinib versus placebo for patients with advanced, metastatic non-small-cell lung cancer after failure of erlotinib, gefitinib, or both, and one or two lines of chemotherapy (LUX-Lung 1): a phase $2 b / 3$ randomised trial. Lancet Oncol 2012, 13:528-538.

12. Cohen BD, Baker DA, Soderstrom C, Tkalcevic G, Rossi AM, Miller PE, Tengowski MW, Wang F, Gualberto A, Beebe JS, Moyer JD: Combination therapy enhances the inhibition of tumor growth with the fully human anti-type 1 insulin-like growth factor receptor monoclonal antibody CP-751,871. Clin Cancer Res 2005, 11:2063-2073.

13. Ji QS, Mulvihill MJ, Rosenfeld-Franklin M, Cooke A, Feng L, Mak G, O'Connor M, Yao Y, Piritt C, Buck E, Eyzaguirre A, Arnold LD, Gibson NW, Pachter JA: A novel, potent, and selective insulin-like growth factor-I receptor kinase inhibitor blocks insulin-like growth factor-I receptor signaling in vitro and inhibits insulin-like growth factor-I receptor dependent tumor growth in vivo. Mol Cancer Ther 2007, 6:2158-2167.

14. Karp DD, Paz-Ares LG, Novello S, Haluska P, Garland L, Cardenal F, Blakely L, Eisenberg PD, Langer CJ, Blumenschein G Jr, Johnson FM, Green S, Gualberto A: Phase II study of the anti-insulin like growth factor type 1 receptor antibody CP-751,871 in combination with paclitaxel and carboplatin in previously untreated, locally advanced or metastatic non-small-cell lung cancer. J Clin Oncol 2009, 27:2516-2522.
15. Jassem J, Langer CJ, Karp DD, Mok T, Benner RJ, Green SJ, Park K, Novello S, Strausz J, Gualberto A: Randomized, open label, phase III trial of figitumumab in combination with paclitaxel and carboplatin in patients with non-small cell lung cancer (NSCLC). In Presented at the 2010 ASCO Annual Meeting; June 4-8, 2010; Chicago, III. Abstract 7500. 2010.

16. Ramalingam SS, Spiegel DR, Chen D, Steins MB, Engelman JA, Schneider CP Novello S, Eberhardt WE, Crino L, Habben K, Liu L, Janne PA, Brownstein CM, Reck M: Randomized phase II study of erlotinib in combination with placebo or R1507, a monoclonal antibody to insulin-like growth factor-1 receptor, for advanced-stage non-small-cell lung cancer. J Clin Oncol 2011 , 34:4574-4580.

doi:10.1186/2162-3619-3-26

Cite this article as: Moran et al: Activity of dalotuzumab, a selective anti-IGF1R antibody, in combination with erlotinib in unselected patients with Non-small-cell lung cancer: a phase I/II randomized trial. Experimental Hematology \& Oncology 2014 3:26.

\section{Submit your next manuscript to BioMed Central and take full advantage of:}

- Convenient online submission

- Thorough peer review

- No space constraints or color figure charges

- Immediate publication on acceptance

- Inclusion in PubMed, CAS, Scopus and Google Scholar

- Research which is freely available for redistribution
C Biomed Central 